\title{
The role of "black capital" in revitalising land reform in Limpopo, South Africa
}

\author{
MICHAEL ALIBER and THEMBA MALULEKE \\ Institute for Poverty, Land and Agrarian Studies (PLAAS), University of the Western Cape
}

\section{INTRODUCTION}

The eastern part of Molemole Local Municipality in Limpopo has experienced a relatively large amount of land reform via both redistribution and restitution. ${ }^{1}$ While in many respects the mix of land reform initiatives in the area is typical - i.e. a fair number of collapsed, semi-collapsed and struggling group-based projects, interspersed with a few struggling-to-promising family-based projects - there are three projects that share a conspicuous feature, whereby a relatively well-off non-beneficiary black investor is attempting to make productive use of land from a land reform project that has either collapsed or failed to materialise. These arrangements take different forms, but in general bear little resemblance to superficially similar arrangements struck in Molemole or elsewhere between land reform beneficiaries and white commercial farmers or agribusiness partners.

The first purpose of this article is to document these arrangements. Secondly, the article attempts to assess the implications of these arrangements for the original beneficiaries; for example, determining the extent to which they have been thrown a valuable lifeline as opposed to having been coerced into an exploitative relationship vis-à-vis the investor. Following this, the third purpose of the article is to speculate as to the extent to which these spontaneous arrangements, or certain elements thereof, provide a basis for a possible strategy to resurrect the large number of failed projects across the country and/or a basis for new models according to which future projects could be designed.

\footnotetext{
${ }^{1}$ While it is difficult to quantify the share of hectares that have been transferred (not least because there is no official or even notional boundary that we can apply to define "eastern Molemole"), if one takes the area within a 20-kilometre radius of Morebeng town, then redistribution projects account for about $9 \%$ of the area and restitution projects for $11 \%$, making a total of $20 \%$. However, bearing in mind that much of the land was not commercial farmland in the first place (for example, some areas of former Venda to the north-east and of former Lebowa to the south-east), the share of commercial farmland that has been transferred is higher, perhaps exceeding $25 \%$.
} 
A theoretically-enlightened analysis of class dynamics is not attempted in this article. In the literature on land reform, class-based analyses tend to assume two over-lapping forms: first, broad political economy treatments which seek to understand how different actors or interest groups attempt to assert their influence on policy in order to advance their cause or safeguard their interests; ${ }^{2}$ and second, Marxist or neo-Marxist analyses in which the history of conflict over land and the prospects for future land reform can be understood in the contest between capital and labour as these manifest themselves in various types of real-world agents. ${ }^{3}$

Our approach falls outside of these paradigms because our purpose is different. ${ }^{4}$ Rather, the paradigm within which we explore these case studies is the more technical consideration of partnership models, by which we mean the various arrangements between land reform beneficiaries (or more generally, "emerging farmers") and various other entities, the common purpose of which is to assist the former to overcome various challenges such as lack of management capacity, lack of access to markets, inadequate capital, etc. A sizeable literature has accumulated since the beginning of South Africa's land reform regarding these models. Moreover, it is presently a theme of intense policy development and scrutiny.

The rest of this article is structured as follows. Section 2 briefly summarises the literature on partnership models, laying a basis for arguing later that our three case studies represent two noteworthy additions to these models. Section 3 seeks to orient the reader regarding the agricultural geography of eastern Molemole and convey a sense of what is happening there by way of redistributive land reform. This is followed in section 4 by a concise presentation of the three project-based case studies. Section 5 compares and contrasts the case studies. The last section concludes the article with brief thoughts as to the policy implications of the evidence presented.

\section{SOUTH AFRICA'S LAND REFORM PROGRAMME AND PARTNERSHIP MODELS}

South Africa's land reform challenge is daunting. One way of appreciating this is to consider what it is not. It is not a land-to-the-tiller type of land reform such as those undertaken half a century ago in Japan and Taiwan, whereby erstwhile tenant farmers were given ownership of the land they farmed at the "expense" of absentee landlords. These types of land reforms consisted of changing the ownership pattern (and thus redistributed wealth

\footnotetext{
2 E.g. Hall, R. "A Political Economy of Land Reform in South Africa" (2004) 31 Review of African Political Economy 213; Lahiff, E. "Redistributive Land Reform and Poverty Reduction in South Africa" LaLR working paper (2007).

${ }^{3}$ E.g. Lahiff, E. "Food Crisis Makes Effective Land Reform an Urgent Priority" Mail \& Guardian 29 August 2008.

${ }^{4}$ Our main concern with the political economy approaches as applied to South Africa is that they tend to assert more deliberateness in the policy-making process than seems warranted, and tend to exaggerate the significance of "forces hostile to land reform" (Lahiff, 2008) relative to more pedestrian explanations of "policy failure" such as a inertia, weak capacity and genuine disagreement as to how to construe more effective policies and to what end.
} 
and re-routed income streams) while allowing for continuity in production systems. Rather, South Africa's land reform is daunting in the Latin American sense, whereby one has to determine how to reconfigure "Junker" estates, i.e. large-scale commercial family farms that rely on mechanisation and wage labour. ${ }^{5}$ What does one do? Carve up the farms and allocate the portions to smallholders? Replace the white farmer with a black farmer?

For a variety of complex reasons, South Africa's Department of Land Affairs (renamed the Department for Rural Development and Land Reform in 2009) chose a third route, namely to replace white farmers with beneficiary groups. Despite revolutionary rhetoric to the contrary, ${ }^{6}$ the Department had no appetite for subdividing farms, seemingly in the belief that it would be best not to disturb the previous owner's production system. ${ }^{7}$ In the land redistribution component of the land reform programme - i.e., that part through which people apply for grants with which to purchase land for farming - as problems with the approach became more evident over time (in particular, intra-group discord), the Department adjusted policy so that groups became progressively smaller, to a point where redistribution projects began to approximate the option of replacing a white farmer with a single black farmer. ${ }^{8}$ For restitution - that part of land reform concerned with the restoration of land or alternative (e.g. financial) compensation to victims of dispossession and/or their descendents - that option is not available. The fact that a farm or farms must be returned to a group rather than a single household is dictated by history, i.e. because it was taken from a group which in the intervening years has likely grown in size. Still, except in rare cases, groups reclaiming land via restitution have been dissuaded by government from dividing it up.

Because a relatively straightforward land-to-the-tiller type of land reform was not available and because of the choices taken, the performance of South Africa's land reform has tended to be poor. The starkest manifestation of this is the prevalence of "collapsed projects", by which we mean land transferred to land reform beneficiaries where agricultural production has ceased and the land was left idle. A review of redistribution

\footnotetext{
${ }^{5}$ Binswanger, H. \& K. Deininger "South African Land Policy: The Legacy of History and Current Options" in H. Binswanger, J. van Zyl \& J. Kirsten (eds) Policies and Markets and Mechanisms for Agricultural Land Reform in South Africa (Oxford University Press, Oxford, 1995).

${ }^{6}$ According to the Reconstruction and Development Programme issued by the African National Congress (ANC) as it came to power: "[The improved quality of rural life...] must entail a dramatic land reform programme to transfer land from the inefficient, debt-ridden, ecologically-damaging and white-dominated large farm sector to all those who wish to produce incomes through farming in a more sustainable agricultural system": The Reconstruction and Development Programme: A Policy Framework (Umanyano Press, Johannesburg, 1994) at 4.3.8.

${ }^{7}$ Aliber, M. \& R. Mokoena "The Land Question in Contemporary South Africa" in J. Daniel, A. Habib \& R. Southall (eds) State of the Nation (HSRC Publishers, Pretoria, 2003).

8 To illustrate: redistribution grants, the purpose of which is to enable the recipients to acquire land as well as some other farming requisites, increased from R16 000 per household in 1995 to a range from R20 000 to R100 000 per adult individual in 2001, to a range from R111 000 to R400 000 per adult individual in 2008. In the early days, therefore, numbers of households would organise to apply collectively so that their grants could be pooled in order to purchase an identified property. With the larger individual grants, this pooling more frequently happens within families.
} 
projects commissioned by the Department of Land Affairs found that, of projects delivered between 2001 and 2006, 29\% could be described as "failed" (no agricultural production and generally deserted) and another $22 \%$ as "declining" (possibly some production, but rendering neither income nor "real benefit"). ${ }^{9}$ The census we conducted in 2008, of all land reform projects in Capricorn and Vhembe District Municipalities of Limpopo, found that in $52 \%$ of redistribution projects and $44 \%$ of restitution projects to date there was no active involvement of beneficiaries at the time of the survey. ${ }^{10}$ In response to what has now accumulated into a large number of failed projects representing significant sums of public expenditure, in 2009 government announced its intention to launch a massive "recapitalisation campaign" to resurrect failed projects. Seemingly, the focus of this effort was expenditure on on-farm infrastructure. ${ }^{11}$

Analyses of what ails land reform are many, and we will not seek to summarise that literature here. What we will observe, however, is that a common perception is that two of the biggest challenges faced by land reform beneficiaries are management and marketing. The "partnership models" (or "joint venture" models) to which we alluded above are in large measure attempts to address these challenges.

Three main partnership models are widely discussed in the literature and to some extent employed in practice: farm worker share equity schemes, strategic partnerships and out-grower schemes. ${ }^{12}$ We describe these briefly.

A farm worker share equity scheme is created when land redistribution applicants are awarded grants with which they purchase equity in a going concern. In principle the idea is that, as co-owners, they will participate in management decisions, have a greater stake in the success of the farming enterprise, and perhaps with time be in a position to take over the farm in its entirety. Equity schemes have been seen as especially appropriate where land costs are extremely high (i.e. because the grants would not be sufficient to enable outright purchase) and/or when the complex nature of the enterprise is such as to require continuity of management. Because of this continuity in management, equity schemes tend to be more able than other projects to secure bank loans. ${ }^{13}$

While some observers regard equity schemes as a preferred model of land reform, ${ }^{14}$ others express concern about the lack of "real" empowerment and the fact that such

\footnotetext{
9 Umhlaba Rural Services “A Review of LRAD Project Performance (2001-2006)” Report commissioned by the Department of Land Affairs (2008).

10 Aliber et al "Livelihoods after Land Reform - Trajectories of Change in Limpopo Province, South Africa" (unpublished research report, forthcoming).

${ }^{11}$ Personal communication, Department of Rural Development and Land Reform (DRDLR), November 2009.

12 This omits another arrangement which seeks to address the question of management, namely mentorships. We omit discussion of mentorships on the grounds that it is not generally a partnership as such, rather just a service provided by the mentor to the mentee.

13 Knight, S. \& M. Lyne "Perceptions of Farmworker Equity-share Schemes in South Africa" (2002) 41(4) Agrekon 356.

${ }_{14}$ Lyne \& Roth write: "A notable exception to the general lack of progress in reform efforts is the success of farm worker equity schemes in South Africa's Western Cape province. These schemes have redistributed
} 
projects often do not create secure tenure, and worry that in too many cases, the only reason the white farmer opted for the scheme was to recapitalise his farm. ${ }^{15}$ Due largely to these same concerns, the Minister of Rural Development and Land Reform called a "verbal moratorium" on equity schemes shortly after assuming office in April 2009, ${ }^{16}$ which was only lifted in early 2011.

Strategic partnerships resemble farm worker share equity schemes, but are more common on restitution projects where the beneficiaries acquire the property outright. Rather, upon settlement of the claim and the transfer of ownership of the property to the claimant community, an operating company is created of which the claimant community owns half the shares or more and the strategic partner the balance. The strategic partner is typically expected to provide the working capital, while the operating company pays a lease to the claimant community for the use of their land and a management fee to the strategic partner. Over the period of the contractual relationship (typically 10 or 15 years), the strategic partner is meant to transfer skills to the claimant community, and also give members of the claimant community first preference in filling vacancies among the farm workers.

In their book, Land reform: Trailblazers; Seven Successful Case Studies, ${ }^{17}$ De Villiers and van den Berg identify strategic partnerships as being responsible for the success of a number of restitution projects. However, other observers lament the fact that the Restitution Commission has in some instances imposed strategic partners on claimant communities, often on terms that are disadvantageous to the claimants. ${ }^{18}$

Finally, an out-grower scheme is an arrangement linking small-scale farmers to an agroprocessor. Although such schemes are neither new nor particularly related to land reform, they are sometimes raised as a possible means of making land reform work better. ${ }^{19}$ The

commercial farmland and wealth while improving agricultural performance": Lyne, M. \& M. Roth "Innovating Institutions to Help Land Reform Beneficiaries" (BASIS Brief Number 8, 2002) at 2.

15 Mini, S., R. Randela \& D. Mayson "Joint Venture Schemes: KZN, Western Cape, Mpumalanga, Eastern Cape" (research report, 2004) available at www.spp.org.za (accessed 25 October 2009). The absence of secure tenure in most share equity schemes is related to the fact that, in acquiring equity in the farm enterprise, beneficiaries do not technically become land owners. However, beneficiaries who take out commercial loans often collateralise their newly-acquired land (indeed, they may use government grants to leverage a mortgage in order to acquire the land), and therefore risk losing their land should they fail to service their loan. The Land and Agriculture Bank is faced with exactly this prospect now, having to repossess almost 200 land reform farms unless government comes to the rescue.

16 Personal communication, DRDLR, November 2009.

17 De Villiers, B. \& M. van den Berg, , Land reform: Trailblazers; Seven Successful Case Studies Johannesburg: Konrad Adenauer-Stiftung (2006).

18 Derman, B., E. Lahiff \& E. Sjaastad "Strategic Questions about Strategic Partners: Challenges and Pitfalls in South Africa's New Model of Land Restitution" in C. Walker, A. Bohlin, R. Hall \& T. Kepe (eds) Land, Memory, Reconstruction, and Justice: Perspectives on Land Claims in South Africa (Ohio University Press, 2010).

${ }^{19}$ See Mini, S., R. Randela \& D. Mayson “Joint Venture Schemes: KZN, Western Cape, Mpumalanga, Eastern Cape" (research report, 2004) available at www.spp.org.za (accessed 25 October 2009); see also Church, A., G. Groom, D. Thomson \& V. Dlamini "Small-scale Cane Grower Development Models: Some Lessons from SubSaharan Africa" Proceedings of the South African Sugar Technology Association 81 (2008) 116. 
idea of an out-grower scheme is that farmers have a contract with an agro-processor, in terms of which they are obliged to sell their output to that agro-processor and in return for which the agro-processor typically provides certain services, such as extension, transport, and sometimes even land preparation.

From the agro-processor's perspective, the purpose of these arrangements is to maintain through-put to the processing facility. Thus, for example, the Transvaal Sugar Company relies on smallholder out-growers for about $18 \%$ of the sugar cane volume that it processes annually. ${ }^{20}$ The advantage to the farmers is that it removes uncertainty from marketing and typically ensures access to services, inputs and support which they might otherwise not receive, some of which is implicitly or explicitly made available as a form of credit, the repayment of which is effected through deductions from payments for the product delivered. For this reason, out-grower schemes are often regarded as especially suitable to small-scale farmers who are less likely to have their own transport and machinery, who often struggle to market their outputs and often fail to access credit. Moreover, the agro-processor's provision of services to smallholder out-growers can benefit from economies of scale, i.e. it can support a number of local smallholders involved in similar agricultural activities at lower unit cost than could an agency supporting a similar number of smallholders involved in different activities.

As in the illustration above, the prototypical example of out-grower arrangements in South Africa is the sugar cane sector, in which some tens of thousands of small-holders in KwaZulu-Natal and Mpumalanga have contracts with a handful of sugar mills. Out-grower schemes have also become common in the timber industry. ${ }^{21}$

The debate about the efficacy of out-grower schemes as a model, hinges on whether or not actual out-grower contracts tend to be exploitative, largely because the agro-processor tends to be able to dictate terms to smallholders. ${ }^{22}$ Another consideration is how much scope there is to create out-grower schemes in different industries, given particularly that there is not always an obvious agro-processor who would wish to embark on one.

Share equity schemes, strategic partnerships and out-grower schemes may all have their place in land reform; however, it is notable that none of these is particularly geared to resurrecting failed land reform projects. For share equity schemes and strategic partnerships in particular, the over-riding goal is to prevent project collapse. This does not necessarily mean that one could not imagine a scenario in which a strategic partner is

\footnotetext{
${ }^{20}$ Rottger, A., A. Dannson, C. Ezedinma, T. Wambua, B. Bashasha, J. Kirsten \& K. Satorius "Strengthening farmagribusiness linkages in Africa: Summary results of five country studies in Ghana, Nigeria, Kenya, Uganda and South Africa" AGSF Occasional Paper 6 (2004).

${ }^{21}$ Cairns, R. "Outgrower Timber Schemes in Kwazulu-Natal: Do They Build Sustainable Rural Livelihoods and What Interventions Should be Made?" Report prepared as part of the South Africa Country Study for the international collaborative research project steered by IIED: Instruments for sustainable private sector forestry (2000).

22 Porter, G. \& K. Phillips-Howard "Comparing Contracts: An Evaluation of Contract Farming Schemes in Africa" (1997) 25(2) World Development 227.
} 
approached for the sake of re-tooling a failed project; however, we know of no instances where this has been done, nor of instances where a failed project has been approached by a potential investor of the same ilk as those who tend to become partners in equity schemes and strategic partnerships. ${ }^{23}$ For out-grower schemes, the main impediment is that such schemes are few and far between, and require a concentration of similarly endowed and focused productive units in close proximity to the agro-processor in order to be feasible. Land reform projects that do not happen to be located close to where such schemes are already operative, have scant likelihood of ever participating in one.

By contrast, the case studies presented below suggest approaches that might have widespread application to failed projects.

\section{ORIENTATION FOR THE CASE STUDIES}

This article draws on research being conducted for a DFID-funded three-country study entitled "Livelihoods after Land Reform" (LaLR). The South African component of the study $^{24}$ focuses on Limpopo Province and, within Limpopo, on two local municipalities, namely Makhado and Molemole (see Figure 1). The focus of this article is on the eastern part of Molemole, near the town formerly known as Soekmekaar, now Morebeng.

Figure 1: Satellite photo of Molemole and Makhado Local Municipalities with geographical features superimposed

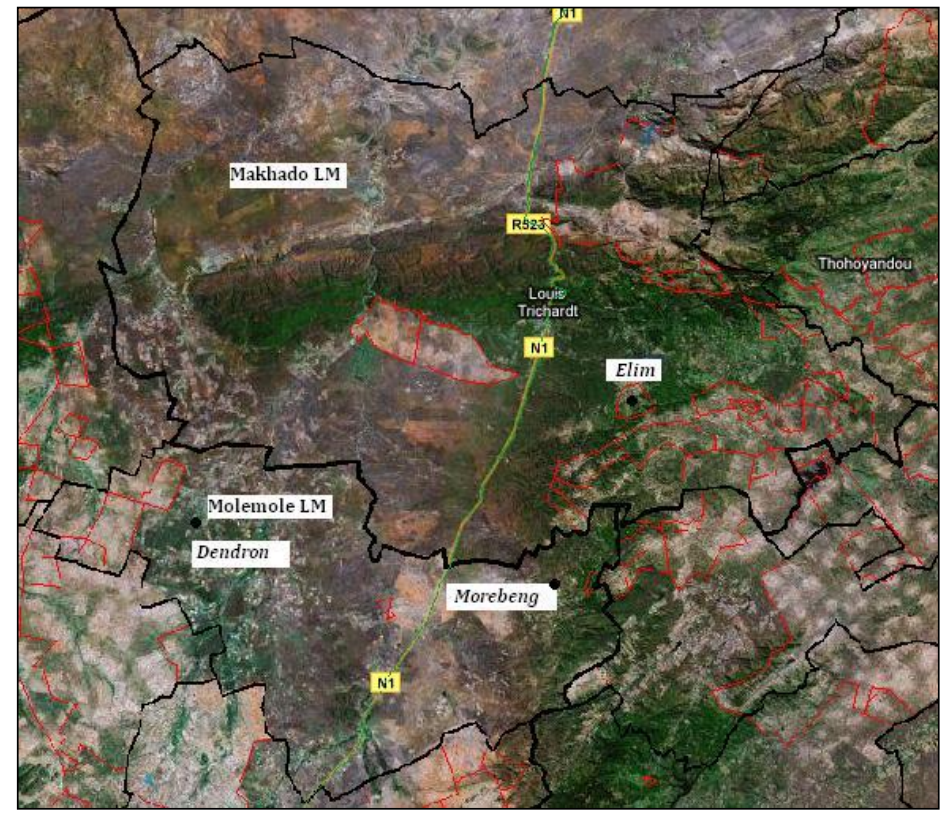

Source: Google Earth with features added using ArcView.

Note: municipalities are delineated in black and "tribal areas" delineated in red

23 The recent experience with strategic partnerships in Limpopo's highly productive Levubu valley, suggests that strategic partners often do not have the capital to keep going concerns going, nor the ability to work closely with land reform beneficiaries (Aliber et al., forthcoming).

${ }^{24}$ Aliber, M., T. Maluleke, T. Manenzhe, G. Paradza \& B. Cousins "Livelihoods after Land Reform - Trajectories of Change in Limpopo Province, South Africa" (unpublished research report, forthcoming). 
What we loosely refer to as "eastern Molemole" or the "Soekmekaar area" (the latter is used particularly when talking about the past) was formerly a reasonably thriving white commercial farming area with a mixture of field crops, horticulture crops, cattle, and timber. Although the town of Soekmekaar was founded only in 1924 "as the rail junction for the Messina, Komatipoort and Polokwane railway lines", 25 white farms had been established from the turn of the century. The pattern of land dispossession was similar to that elsewhere in Limpopo: white farmers would settle in an area amidst black communities; they then announce that they owned the land of which the boundaries had in the meantime been surveyed by the (white) government; black families would be required to furnish a certain amount of unpaid labour per year (usually three to six months for men, and two weeks per month for women), failing which they would be required to leave; and, over time, more and more households would be regarded as excess relative to white farmers' needs and would be forced to leave. ${ }^{26}$ The process of dispossession was therefore often protracted and labour tenant labour was gradually replaced with wage labour.

The agricultural conditions in the area are generally favourable due to its location on the cusp of the escarpment, which moderates temperatures and assures relatively ample rainfall. ${ }^{27}$ However, despite this, as well as the advantage of easily accessed rail transport with which to move products to market, commercial farmers in the Soekmekaar area stuck to maize, potatoes and cattle through most of the $20^{\text {th }}$ century. Only from the $1990 \mathrm{~s}$ did farmers start to diversify significantly into tree crops and horticulture (especially strawberries). The reason appears to be that marketing controls and subsidies were such that farmers could make a reasonable living without having to explore other commodities. According to Albert, a local white farmer, "[farming is] more difficult now than in the past, but it was never easy; in the past, the okes just got by". ${ }^{28}$ However, an additional reason may be that farms in the area did not get electricity until 1988, which thereafter facilitated irrigation. Those white commercial farmers who are left are still either intensifying or trying to expand, though expansion is mainly possible only by leasing farms from land reform beneficiaries.

While there are no secondary data with which to depict trends in farm employment, interviews with commercial farmers suggest countervailing processes over the past 10 to 15 years. That the area was plagued by ongoing problems of farm evictions is evidenced by the fact that the first ANC attack on a police station was that of Soekmekaar in January

\footnotetext{
${ }^{25}$ Aucamp, I. \& J. de Beer "Social and Tourism Impact Assessment for the proposed Spencer - Tabor 275kV Transmission Line" (report commissioned by Eskom, 2007).

26 Aliber et al (fn 24 above).

27 Weather station data reveal that, on average, the area immediately around Morebeng receives far more rainfall than areas to the west such as Bochum and Bandelierkop, and more even than Ga-Ramakgopa, which is only about 20 kilometres away. Indeed, those who were forcibly removed from Soekmekaar and the farmland immediately surrounding it were typically moved to the drier areas to the west such as GaRamakgopa, Eisleben and Matoks. Even so, it is worth noting that in the satellite image below the "swirly pattern" immediately south of Ga-Ramakgopa and west of Eisleben covers plots which until relatively recently were regularly used for staple food production.

${ }^{28}$ The names in this paper are made up.
} 
$1980 .{ }^{29}$ On the one hand, the diversification into high-value crops means greater demand for permanent workers relative to seasonal workers, but overall an increase in the wage bill. On the other hand, the transfer of land through land reform has reduced overall demand for labour on white-owned commercial farms, while employment and selfemployment on transferred properties is variable according to the overall performance of the projects, about which we say more below.

Figure 2: Satellite image of the "Soekmekaar area"

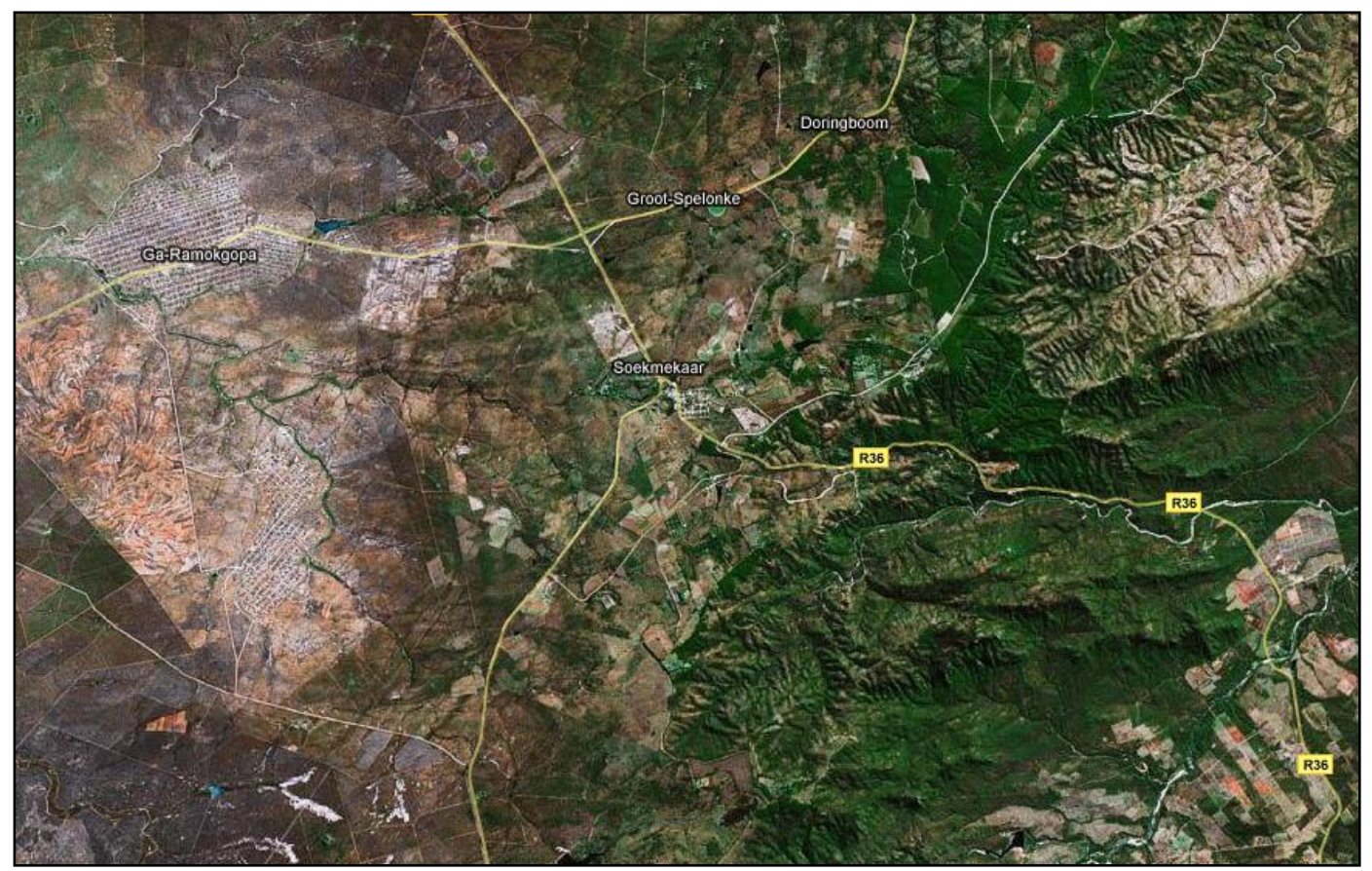

Source: Google Earth

Presently, much of the land has been transferred via land reform to black owners, and the extent of commercial farming in the area is dramatically diminished. ${ }^{30}$ One sign of this is the closure of NTK's shop - the main source of agricultural supplies within 100 kilometres or so - in 2001. ${ }^{31}$ Another indicator is an off-hand remark of one of the main companies that provides agricultural transport to the region (based in Mooketsi, roughly equidistant between Morebeng and Tzaneen) to the effect that "there really aren't any commercial

\footnotetext{
29 "Petrus Mashigo [one of the three accused] told the court that the attack on Soekmekaar police station had been intended as 'armed propaganda' in protest against the forced removal of the community in the area. It was intended to show the ANC sympathised with the plight of the people and to demonstrate to police that what they were doing was wrong": African National Congress "Statement to the Truth and Reconciliation Commission" (1996) available at www.anc.org.za/ancdocs/misc/trc06.html (accessed 12 August 2008).

${ }_{30}$ As of 2008, about 22000 hectares had been transferred via land reform; we cannot say precisely what share of the commercial farmland in the area this represents but venture to say that it is roughly $30 \%$ to $40 \%$. 31 This shop remained closed for two years, and was subsequently re-opened as one of NTK's so-called "depots". These "depots" are how NTK serves its predominantly black clientele. There are nine depots in the province, mostly in the Venda region, under centralised management. By contrast, each of the 24 shops which offer a wider array of products including machinery and equipment - has its own manager.
} 
farmers in Soekmekaar anymore". ${ }^{32}$ But, more to the point, the primary project-level data collected in the course of LaLR establishes that eastern Molemole has experienced a rather typical mix of land reform projects, from those that are completely moribund to those that show some sign of "success" in terms of maintaining at least some agricultural production. Table 1 below draws on data generated from the project census conducted as part of LaLR:

Table 1: Status of projects in eastern Molemole

\begin{tabular}{|l|c|c|c|c|}
\hline & Redistribution & Restitution & \multicolumn{2}{|c|}{ Both } \\
\cline { 4 - 5 } & (number) & Number) & Sumber & Share \\
\hline $\begin{array}{l}\text { No beneficiaries using land, nothing } \\
\text { happening }\end{array}$ & 6 & 1 & 6 & $32 \%$ \\
\hline $\begin{array}{l}\text { No beneficiaries using land, but some } \\
\text { leased out }\end{array}$ & 1 & 0 & 4 & $21 \%$ \\
\hline Some beneficiaries using & 4 & 1 & 5 & $26 \%$ \\
\hline $\begin{array}{l}\text { Some beneficiaries using, and some land } \\
\text { leased out }\end{array}$ & 4 & 1 & 2 & $11 \%$ \\
\hline Unknown & 16 & 3 & 19 & $100 \%$ \\
\hline \multicolumn{1}{|c|}{ Total } & & & & 2 \\
\hline
\end{tabular}

Source: Aliber et al, forthcoming

However, it would be rash to conclude that the decline in agriculture in eastern Molemole was a consequence of land reform. This might be the case, or might be so partially, but there are indications that the commercial farming community of eastern Molemole began to decline prior to and independently of land reform. Most obviously, the NTK shop closed before a significant share of land had shifted hands. Secondly, while initially white commercial farmers banded together to oppose land claims, once one of them realised this was a good opportunity to get out of farming others quickly followed suit. From remaining white farmers interviewed the impression emerges that it was not because farmers were particularly eager to sell, but rather because "[government] started to throw cash on the table", offering valuations local farmers by and large regarded as "extremely good". "If a good opportunity arises," according to Gerhard, a local white farmer, "you'd be stupid not to take it." What we can say with certainty is that the agricultural character of the area has changed dramatically, and probably not for one single, simple reason.

\section{THREE CASE STUDIES}

This section briefly presents three case studies, namely of two older redistribution projects, named Marobala Chicken and Mmatshehla Trust, and one more recent restitution project undertaken on behalf of the Morebene Community. The location of these projects is

32 Dot, transport company manager. 
indicated in the map below, which also shows the location of towns and villages referred to in the case studies.

Figure 3: Location of three case study projects*

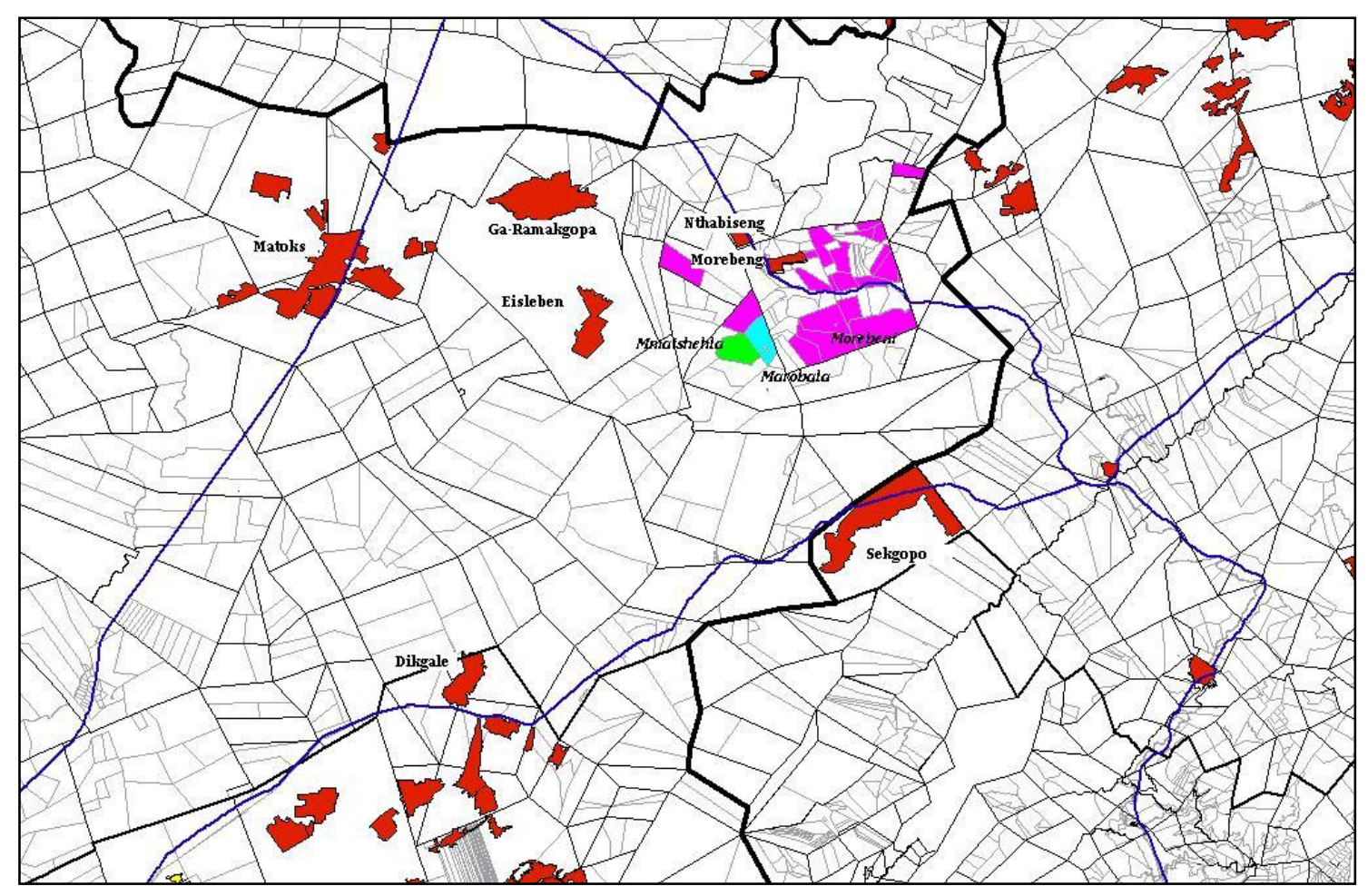

Source: Aliber et al., forthcoming, using data from the Department of Land Reform and Rural Development and the Restitution Commission

* Does not show full extent of land restored to the Morebene Community

\section{Marobala Chicken Trust}

Marobala Chicken Trust is a redistribution project funded under the SLAG programme of the Department of Land Affairs. ${ }^{33}$ It is typical of early SLAG-based redistribution projects in that it initially comprised a large group of 88 beneficiary households. Most of the project members belong to the Marobala people and come from the village of Marobala, which falls under Dikgale. ${ }^{34}$ Dikgale is 35 kilometres east of Polokwane and 26 kilometres west of Morebeng. The fact that the property ended up as a land reform project is due to the previous owner's decision to sell; in 1997 he began organising a beneficiary group (of whom four were workers on his farm) for purposes of acquiring his farm through land

33 "SLAG" stands for the Settlement/Land Acquisition Grant, which was the main financial vehicle for the Department of Land Affairs' redistribution programme during the period 1995 to 2000. See fn 4 above.

${ }^{34}$ Why the project is called "Marobala Chicken" is more obscure, given that the project has never focused on chicken or egg production. Perhaps there was early discussion of starting a chicken enterprise, and having the word "chicken" as part of the title served to distinguish this project from another one called Marobala-OItsose. 
reform, and in 1999 the transfer was effected. The farm - portion 6 of Driefontein 777 LS is situated 3 kilometres from Morebeng and comprises 232 hectares. According to former farm workers, the previous owner appeared to run the farm profitably and used the land to full capacity.

When they got the land the beneficiaries had expectations that they would run the farm as a community, accumulate wealth for the first time in their lives and even employ more people. For a while (we are not too clear how long) the project functioned reasonably well and members were paid (i.e. paid themselves) R1 000 per month. One of the remaining active members ascribes the collapse of the project to poor management, and specifically alleges that the project leaders "paid themselves big salaries and forgot about the operational costs". However, even if this were untrue, the farm could probably not sustain anything close to R1 000 per month for 88 members when previously the number of employees was only nine. Following a brief period of euphoria (of which the high point was a helicopter visit from the State President to praise the progress of land reform in front of camera crews), the project deteriorated to a point where by around 2001 or 2002 there were only around six remaining members. A production loan taken out near the beginning of the project is still owing to the Land Bank.

Interestingly, of the six remaining members, four are the four former farm workers who had been incorporated into the project at its inception. All reside in nearby townships/locations, though they stay in the farm's dilapidated farm house on occasion. Why have they stayed? "Where else can we go? We are poor and the little we get is helping us until something comes up". The suggestion is not so much that as former farm workers they have the keenest interest in farming, but that they have fewer alternatives.

What is happening currently on the land? Most of the non-arable land is leased out to a local white farmer who is grazing some of his livestock there. There is a small avocado orchard which is not properly tended but still produces some fruit which people from the "community" at large harvest at will. For two or three years, three of the remaining members produced maize and potatoes on a small scale for both household consumption and sale, but this has recently ceased.

As of late 2007 the main activity on the property has been that of a black tenant named Abraham. Abraham leases 10 hectares of arable land from the group for which he pays R36 000 per year in addition to paying for electricity monthly. This is by far the largest source of income to the beneficiaries. Abraham is currently using only 4 hectares on which he has 16000 head of cabbage, but intends to extend operations to the other 6 hectares shortly.

Abraham employs six people to work on the land he is leasing, of whom two are women beneficiaries of the project and the other four are young men from the community where he comes from. He pays them each R800 per month. Abraham's profits thus far have been minimal, owing largely to crop damage from wild animals and others' cattle, which means that he has marketed far less than intended, and generally in local markets rather than the 
formal markets he had been targeting. However, he is confident that he will solve this problem. His bigger worry is that the project still owes money to the Land Bank, which he (accurately) doubts the remaining beneficiaries are servicing with help from his rental payments; there is thus a risk that the Bank can repossess the land. Indeed, it seems that, of the six remaining members, the four men mainly "remain" in order to tap into the lease payments as and when they arrive (see Philemon's story, below).

\section{Merriam}

Merriam is one of the remaining beneficiary members on Marobala. Merriam was born on Driefontein, though on a part that has since been divided off into a separate operational unit and is presently owned by someone else. Her parents were farm workers. She explains that when she was growing up, white farmers were very cruel to black farm workers; for example, they would not pay salaries for months at a time, counting on workers' extreme dependence for their jobs and homes. When Merriam left the farm she already had her first child although she was very young. She never attended school. She went to work at various other farms in the area until she ended up on portion 6 of Driefontein in 1983. Merriam learned about land reform from the owner of portion 6 together with the others who were working for him at the time. Merriam is presently about 45 years old and resides in "East Level" (Eisleben). However, she stays on the farm during the week when there is a lot of work to do for Abraham.

\section{Philemon}

Philemon was born in 1956 on the very same farm where he is presently one of the few remaining beneficiaries. He went to school until grade 5 , which was as far as the local farm school went. Philemon started working on the farm at around the age of 14 , where he looked after the livestock, worked in the fields and performed other tasks. When he was 22 he went to Johannesburg where he worked as a messenger at a butchery. After 10 years he moved to Polokwane where he found work in a bakery. After nine years the bakery closed down and he lost his job. Failing to find another job, he came to rely on his eldest child who by then was working as a school teacher.

As he tells it, Philemon first heard about land reform in 1998 when the government went out and "recruited people to register their names as beneficiaries". He registered to be one of the beneficiaries of the project at Driefontein. His expectation at the time was that people would continue to farm as the previous owner had and that their lives would automatically improve. He now stays at the farm and goes to Dikgale village on weekends, where his wife and children are staying. He claims to have been nominated to "look after the house"; however, some of the other members allege that this is a ploy to justify his waiting around to appropriate a share of the rent from the lessee when he makes his occasional payments. As far as the situation on the farm is concerned, he does not think the project will ever improve. He therefore wishes people with money would come to lease the other parts of the land and the beneficiaries get the rent, because using the land has proven to be very difficult for the beneficiaries. However, at his stand in Dikgale his wife farms maize and watermelon on a small plot. 


\begin{abstract}
Abraham
Abraham was born 33 years ago at Dikgale village. He passed standard 10 and went to a technical college in Polokwane to train as an electrician. He is married with one child. When he was growing up he was never involved in agriculture, though his father had an interest in farming. His father used to lease land from a neighbour and he used to hire people to work the land.

Abraham has never been employed but has assisted his father in managing the latter's various businesses. Presently Abraham is involved in two of these, namely a driving school located in Dikgale and the farming enterprise at Marobala.
\end{abstract}

\title{
Mmatshehla Trust
}

The Mmatshehla Trust project is another SLAG project in the Morebeng area. It occupies portion 7 of the same farm, Driefontein, where Marobala Chicken is located. Portion 7 which the previous owner farmed as a distinct operational unit - consists of 396 hectares and was transferred to 60 beneficiaries in 1999.

As with Marobala Chicken, most of the Mmatshehla beneficiaries are from Dikgale village, though some are also from Matoks. Dikgale falls under chief Solly Dikgale, who demonstrated a passion for promoting land reform projects (four or five land redistribution projects in the area were actively encouraged by him), into which he typically recruited members of villages under his authority. A small number of the beneficiaries of Mmatshehla were former workers on the farm who were integrated into the beneficiary group as the application was being developed.

For a while, following the acquisition of the land, the beneficiaries were very active in farming crops like maize, pumpkins, beetroot and spinach. Apart from the land and its structures they acquired from the previous owner a bakkie, a tractor, three water pumps, a cattle kraal and a pigsty. They also managed to purchase some cattle with the "balance of the grant". However, after about a year and a half the commitment of beneficiaries began to wane, seemingly because they felt their efforts were not matched by sufficient reward. As the cohesion of the group collapsed a period of chaos ensued and beneficiaries - and then non-beneficiaries in the vicinity - started to strip the project's assets, not least the water pumps and other irrigation infrastructure. By 2006 the number of active beneficiaries had shrunk to six, of whom two are former farm workers from the farm.

In 2007 the beneficiaries were approached by Mr Tshilipo, who wanted to lease some of their land. Mr Tshilipo's son, a medical doctor, had a friend in the provincial agriculture department through whom $\mathrm{Mr}$ Tshilipo arranged an introduction to the remaining Mmatshehla beneficiaries. An agreement was struck and Mr Tshilipo began production right away. At the same time Mr Tshilipo arranged with the six remaining beneficiaries to work for himfor three weeks per month at a monthly rate of R500. 
The terms of the lease agreement are that Mr Tshilipo is to pay R1 000 per month. However, this includes approximately R500 for electricity which is mainly for his own benefit, i.e. to run the pump for his irrigation. Following the theft of this pump Mr Tshilipo replaced it, and thus most of the rest of the other R500 is now going to compensate $\mathrm{Mr}$ Tshilipo for this expense. It is difficult to reconstruct how happy the remaining beneficiaries were with the lease arrangement when it was first struck. Now, however, there is a subdued but palpable sense of grievance. When asked to elaborate on their feelings about the arrangement with Mr Tshilipo, the beneficiaries/employees offer little, conveying a sense of wariness more than indifference. Amazingly, according to Mr Tshilipo, the lease agreement is valid for nine years.

As for Mr Tshilipo's agricultural activities, he is cultivating about 8 to 10 hectares under irrigation, focussing on strawberries as well as other crops such as beetroot, onions, peppers and maize. Strawberries are one of the main cash crops among commercial farmers in the area. Mr Tshilipo is still in the process of expanding. He also keeps about 80 pigs in the old pigsty, though he is having difficulty with marketing because, according to him, nearby abattoirs do not trust black farmers.

\section{Phineas}

Phineas was born at a farm near Makotopong, 15 kilometres east of Polokwane, in 1945. During his childhood and youth he and his parents moved to other farms in the area. He recalls as a child looking after the white owner's livestock while also contributing to his own family's agricultural production, probably indicating that his parents were labour tenants. While on the farms Phineas learned various skills, such as how to operate a tractor. However, he didn't attend school as there was little access to schools on the farms. When he was 14 he did have an opportunity to attend school but struggled to make a start at such a late age.

In 1961 Phineas went to Johannesburg and worked as a "garden boy". He worked there for five years, then returned to Limpopo and resumed work as a farm labourer. He got married in 1968 and in 1969 went to Vereeniging where he worked for a sewage company. However, after a year or so he again returned to Limpopo and again resumed farm work. In 1988 he started working for Joggie Grobelaar, the previous owner of portion 7 of Driefontein. He felt Joggie was kind relative to most of the other white farmers he had worked for. Around 1988 government officials came to the farm to explain land reform to the workers. The workers were happy because "we were told about being rich and we were convinced about it as we were told by government". After the land was transferred and things started to decline he noted that many beneficiaries abandoned the project because "they were not hungry". He stayed because he knows farming better than any other way of life. 
At the moment Phineas thinks things are not that bad, as he can support his family through the salary he is paid by Mr Tshilipo. He works three weeks a month like other farm workers, but his salary is more than that of the others because he is a tractor driver whereas they are just general workers. Phineas also mentioned that, as beneficiaries, they also allocated themselves plots where they plough their own maize, but for the last season they didn't plough due to lack of resources.

\section{Mr Tshilipo}

Charles Tshilipo comes from Matoks but ethnically belongs to the Mashamba people who trace their roots to the former Venda homeland. He is presently 61 years old. After passing matric in 1967, he took menial work in Johannesburg because his family did not have resources to allow him to proceed to further studies. However, in 1969 he embarked on a two-year qualification in teacher training. His teaching career lasted for 37 years, ending in 2007. For the last 20 years or so of his career he served as headmaster of a secondary school in Sekgopo village, south of Morebeng. Along the way he acquired further qualifications, including a bachelors degree from the University of Venda and a diploma in education management from the then University of the North.

Mr Tshilipo had an interest in farming from a young age (his father had draught animals and other livestock as well as a number of fields) but never considered pursuing a career in farming because it was regarded as a lowly activity. In 1973 he got married to his wife, who was also a teacher. They have three sons, of whom one does administrative work in a company in Johannesburg, one is a mechanical engineer at Burgersfort and one is a medical doctor in Polokwane.

\section{Morebene Community}

From the data acquired from the Restitution Commission we know that the land restored to the Morebene Community thus far encompasses 6647 hectares, and the claimant group consists of 590 households. Most of this land was restored in 2004. Until late in the fieldwork phase of LaLR we were unable to learn anything more about the Morebene Community because they refused to speak to us. This seemed to relate to a profound degree of in-fighting that had created an atmosphere of general mistrust. What we now know about the project is thanks mainly to the Gauteng-based grandson of one of the claimants.

The story goes that, following the restoration of the land to the community, relatives of the community's traditional leader (who also represented the community through the claims process) asserted their right to some of the land, then sold the timber from two of the farms to a private company and ran off with the proceeds. These two farms now lie fallow. On the rest of the land, most of which was previously for mixed use, nothing was happening due to lack of resources, lack of a plan, lack of consensus and, arguably, lack of 
effective leadership. Most of the claimant households live 20 or more kilometres away from the land, e.g. in Ga-Ramakgopa and Matoks to the west. None of the claimant households has returned to settle on the land.

Around 2006 Ephraim M., the aforementioned grandson, decided he would try to do something about the moribund state of the project. He proposed to the claimant community that he would assist claimant households to farm on household plots demarcated on two of the community's restored farms, in exchange for which he would be afforded access to two farms for his own use. Precisely how he obtained agreement with "the community" is not entirely clear, but it is evident that he felt sufficiently secure to begin operations on the two farms designated for this purpose. Given that Ephraim is a Gauteng-based professional and moreover has little personal experience of farming, he needed a farm manager. For this he teamed up with Herman, an Afrikaans man he happened to meet at the fresh produce market in Polokwane. The two farms managed by Herman are operated in a fashion similar to any other white commercial farm in the area. These farming operations began in the 2006/07 season. Presently they are focusing on potatoes, sweet potatoes, maize, strawberries, and various vegetables. They employ 44 workers from the claimant community on a full-time, regular basis, plus about three times as many seasonal workers.

However, apart from managing these two farms, Herman is a de facto on-site extension officer to claimant households working on plots on the other two farms designated for this purpose. In the 2007/08 season there were roughly 35 households from the claimant community farming their own plots, on whose behalf Herman organised land preparation and provided seeds and advice. A member of the claimant community was hired to assist households to demarcate their plots. In 2008/09 there about 60 such households receiving support, but these were complemented by over 100 other claimant households planting small plots of maize on the land, who did not receive direct assistance from Herman in doing so.

\section{DISCUSSION}

One obvious point to begin with is that there is indeed a discernible class difference between the investors/lessees on the one hand (i.e. Abraham and his father, Mr Tshilipo and his son, and Ephraim and Herman), and the beneficiaries from whom they are leasing. This has not been carefully established or documented above, but it is clear first of all just by virtue of the resources that the lessees are able to mobilise, and also through some of the brief biographies presented. In terms of the biographies of some of the beneficiaries (i.e. those of Merriam, Philemon and Phineas), common denominators include coming from farm worker (i.e. labour tenant) families and little education. This is not to say they have no experience outside of farm work (Philemon and Phineas both worked in Gauteng, for instance), but their "chances in life" appear to have been strongly conditioned by the 
marginal social and economic status of the families from which they come. While there is little concrete evidence by which to contrast them to the relatively large number of project beneficiaries who have since abandoned the projects altogether, there are suggestions that, even relative to them, Merriam, Philemon and Phineas are marginal. For example, Phineas comments that those who left the projects "do not know hunger"; in explaining why she has remained active on Marobala, one woman answers with a question: "Where else can we go?"35

The lessees, on the other hand, did not grow up as part of farm worker families, though their families may have been involved in agriculture. For Abraham and Mr Tshilipo the family background rather suggests "petty bourgeoisie", which is not to say a complete absence of hardship. Although we know less about Ephraim's background, other than that his family was forcibly removed from Soekmekaar to Ga-Ramakgopa when Ephraim was a child (he is currently in his late 30s), his parents were town-dwellers prior to this event. The education and career histories of the three lessees also reveal that they belong to families characterised by upward mobility, whether through entrepreneurship or acquiring credentials as professionals. Having said this, at least for Abraham and Mr Tshilipo there remains a large gap between themselves and typical established white commercial farmers. It is difficult to say for certain whether this is on account of less wealth or the fact that their farming enterprises are at an early phase of development. However, it is interesting to note that Abraham hires tractor services from neighbouring white commercial farmers because he does not have his own. Mr Tshilipo, meanwhile, relies on the assistance of neighbouring commercial farmers to market his strawberries, because he does not have enough volume on his own to achieve favourable transport arrangements in getting his strawberries to markets in Gauteng and beyond. Only Ephraim appears to have been able to leap into largescale commercial production; although his personal circumstances are not clear to us, it is probably no coincidence that, unlike Abraham and Mr Tshilipo and their respective families, Ephraim's business ventures are centred in Gauteng rather than in the "backwaters" of Limpopo Province. ${ }^{36}$

Do remaining beneficiaries benefit from these arrangements? Yes and no. For Marobala and Mmatshehla the rent paid is not significant, at least not in principle. For Marobala, the rent in theory should be used to help pay of the Land Bank loan, so the benefit would be an indirect one, i.e. not losing the land. However, how the money is actually used is unclear, but even split six ways it is only R6 000 per remaining beneficiary per year. For Mmathshehla the rent now goes almost entirely to electricity and refunding Mr Tshilipo for the cost of replacing one of the pumps. While technically the pump belongs to the

\footnotetext{
35 It is important to recall that this question should not be understood to refer to where can they go for residential purposes; all of these remaining beneficiaries have homes in nearby villages.

36 This is obviously a bit strong (apart from being rather speculative), noting, for example that some of $\mathrm{Mr}$ Tshilipo's children are well established in Polokwane and Gauteng. However, based on this and other evidence from LaLR, there appears to be a tangible difference between being able to tap into one's own resources and having to rely on those of a family member.
} 
beneficiaries, in practice its only use is to support Mr Tshilipo's farming enterprise, thus explaining the beneficiaries' sense of dissatisfaction. For Morebeni, the "rent" paid by Ephraim comes in the form of material assistance to 60 plot farmers on adjacent farms. We have not been able to place a value on this, but from what we know it appears that all of this "rent" is indeed for their benefit.

Wages paid by the tenants are more significant. For Marobala, the annual wage bill is almost R58 000, or R9 600 per worker. However, only two of Abraham's six workers are in fact from the group of remaining project beneficiaries, so the total wage income accruing to beneficiaries is only R19 200. For these two women beneficiaries it is a livelihood comparable to what they would earn on a white commercial farm under conditions that appear to be favourable in some ways, though less so in others. Still, from a programme perspective, it is sobering to think that government spent over R1.3 million in order that two beneficiaries may earn the minimum wage on their own land.

For Mmatshehla, the wage bill is only R36 000, but it accrues to all six of the remaining beneficiaries. Lastly, for Morebene, we do not know what benefits are derived by the 70 plot-farming claimant households, nor how we should compare these largely in-kind benefits to what appears to be the steady wage income received by remaining beneficiaries on the other two projects. Very likely it would prove to be less than the R9 600 per worker per year at Marobala, or even the R6 000 per worker per year at Mmatshehla. What is notable, however, is that such a large number of households derive at least some benefits, and if Ephraim and Herman have their way this will increase further in the future.

Are these arrangements exploitative? We are not able to answer this definitively, but what we do observe is that, even while the rental terms set by Abraham and Mr Tshilipo are not generous, ${ }^{37}$ it is far from the case that either gentleman is making a killing, at least now. Their nascent enterprises are fragile and they could not reasonably be expected to pay significantly more. Moreover, as a matter of principle, it is not clear to whom the rental income should accrue. To pay it over to the remaining beneficiaries is fairly arbitrary; yet, if it were divided up among all the original beneficiaries, then on a per-beneficiary basis it could only ever be trivial. As such, for Marobala, paying rent which can be used to prevent foreclosure by the Land Bank would be eminently fair (however unintentionally), although we understand this is not exactly what is happening there.

For Morebene, it is not possible to arrive at a precise sense of the fairness of the current arrangement, except it is noteworthy that, in supporting 60 plot farmers, Ephraim's and Herman's costs are quite modest (probably in the order of R15 000, or about one-third of our estimate of a market rental of R45 000 for the land they are using for own account); and yet somehow the positive spin-offs are widely shared if not great in imputed value. Even if a full market rental were to be paid, divided over 590 households it would be of no

37 To be precise, we are not in fact clear who set these terms, in particular whether it was not the local agriculture office, who acknowledge assisting in brokering these rental arrangements but state that they do so in part to protect the interests of beneficiaries. 
consequence. It is clear that the rental paid is not a useful measure of the fairness of the arrangement; rather, it is the less easily quantified measure of benefits that flow to project members on account of the investors' presence, which in the case of Morebene now includes over 150 smallholders, 44 regular jobs and up to 100 seasonal employment opportunities.

While we are not in a good position to judge the relative fairness or even the desirability of the different arrangements, perhaps what is most revealing is the contrast between Ephraim's and Herman's approach on the one hand, and that of Abraham and Mr Tshilipo on the other. Why did Ephraim and Herman not choose to go the route of Marobala or Mmatshehla? Why, for example, did they not merely seek to access as much of the restored land as possible, in return for which they could offer jobs? Or, in addition to offering jobs, they could have adopted the typical land reform model whereby "the community" operates a unified commercial operation with their assistance, perhaps as major shareholders in a registered business? Asked to explain their approach, Ephraim's stated reason is telling: first, because a farming model for claimant households based on small independent plots would absorb more labour (in contrast to the unified commercial farm model, which tends to do the opposite); and, second, because individual plots would ensure a stronger link between people's initiative and their reward, which implies individual responsibility. To all appearances, Ephraim approached the problem as a policy-maker rather than an entrepreneur, whereas the latter might have dictated a different approach.

\section{CONCLUSIONS}

While our preliminary glance suggests that what Ephraim and Herman have offered Morebene is more significant than what Abraham and Mr Tshilipo have offered Marobala and Mmatshehla respectively, it is also reasonable to conclude that the more conventional rental approaches of the latter two are nonetheless "better than nothing". Much will depend on whether Abraham and Mr Tshilipo are able to grow their businesses, which in any event are reasonably labour-intensive, and have significant scope for expansion. Given that they are both employing more or less the same number of workers as the previous owners of the farms they are presently leasing, there is potential to increase employment beyond what was there before. However, the benefit will remain one of creating wage employment, which is not a principal objective of land reform. Or perhaps one should tally Abraham and Mr Tshilipo as de facto beneficiaries of land reform as well, even though they do not feature on the official beneficiary list? Perhaps, but the "poorest of the poor" they certainly are not.

What is arguably most striking about the case of Morebene is that two contrasting farm models now operate side by side; that is, the designation of small family-based semisubsistence plots on the one side versus the capital-intensive unified commercial farming enterprise on the other side. It would be going too far to suggest that they do so 
synergistically, in that it is difficult to see what benefit the large-scale mechanised operations (i.e. those for Ephraim's and Herman's account) derive from the plot farmers except that, by virtue of being labour-intensive plot holders, they are likely in the short run to exert little pressure on the available land, meaning that Ephraim and Herman can continue their operations without fearing competition over land from within the community. On the other hand, offering support to their smallholder neighbours is presumably relatively easy and inexpensive, given that their commercial farming enterprise is right next door. It remains unclear whether the juxtaposition of these different models at Morebene is an expression of an underlying economic logic that at present we do not fully understand or a tension that only remains contained thanks to Ephraim's and Herman's curious combination of entrepreneurial shrewdness and intelligent generosity. If the former, in principle it could be both better understood and promoted as a matter of policy; the latter, however, is probably less amenable to replication via policy.

It remains to compare these lessee-beneficiary arrangements to those between commercial farmer lessees and project beneficiaries, as well as to the partnership models described above. Our casual impression of arrangements involving white lessees is that these lessees rarely make any investment in the property, rarely hire beneficiaries as workers and predominantly focus on securing access to additional land with as little interaction with the beneficiaries as possible. ${ }^{38}$ As shown above, the benefits of this are limited precisely because land rental tends to be low relative to the wage bill, especially where the land is used for arable production.

As for partnership models such as equity schemes, strategic partnerships and outgrower schemes, our three case study projects would appear to be the kind of scenario that well-heeled partners from the world of agri-business would generally avoid. In the case of Marobala Chicken and Mmatshehla, the amount of land involved is small and the overall potential highly limited, combined with the fact that the beneficiary groups are disorganised if not divided. While the Morebene community owns much more land and therefore offers real scope for expansion, the potentially lethal group dynamics are such that a truly external investor would be foolhardy to get involved. Failed projects failed for a reason, and not just any partner would be eager or able to step in and pick up the pieces. Based on these admittedly limited case studies, our surmise is that small-scale black investors are relatively well suited, if not uniquely so, to involve themselves in failed land reform projects, but that there is a range of ways in which this is possible.

\footnotetext{
38 One white farmer interviewee in the area expressed precisely this. After experiencing water shortages on his farm to the west of the N1 near Vivo, he decided to access land in the more favoured Morebeng area by leasing it from land reform beneficiaries there. Initially he struck a partnership arrangement with one of the SLAG-based redistribution projects in the area whereby he hired some of the beneficiaries as workers, helped them pay off their Land Bank loan and attempted to farm. When this proved unworkable he initiated a lease arrangement with a different land reform group, where he emphatically limited his interaction with the group to the rental agreement itself (Johann, local white farmer).
} 
What should also be clear from the case studies is that merely throwing infrastructure at failed projects is not necessarily a meaningful approach to resurrecting them. Given that there are literally hundreds of collapsed land reform projects around the country, these three case studies of spontaneous asymmetrical arrangements offer some ideas for interventions of potentially huge relevance.

\section{REFERENCES}

Aliber, M. \& R. Mokoena "The Land Question in Contemporary South Africa" in J. Daniel, A. Habib \& R. Southall (eds) State of the Nation (HSRC Publishers, Pretoria, 2003).

Aliber, M., T. Maluleke, T. Manenzhe, G. Paradza \& B. Cousins "Livelihoods after Land Reform - Trajectories of Change in Limpopo Province, South Africa" (unpublished research report, forthcoming).

African National Congress The Reconstruction and Development Programme: A Policy Framework (Umanyano Press, Johannesburg, 1994).

African National Congress "Statement to the Truth and Reconciliation Commission" (1996) available at www.anc.org.za/ancdocs/misc/trc06.html (accessed 12 August 2008).

Aucamp, I. \& J. de Beer "Social and Tourism Impact Assessment for the proposed Spencer Tabor 275kV Transmission Line" (report commissioned by Eskom, 2007).

Binswanger, H. \& K. Deininger "South African Land Policy: The Legacy of History and Current Options," in H. Binswanger, J. van Zyl \& J. Kirsten (eds) Policies and Markets and Mechanisms for Agricultural Land Reform in South Africa (Oxford University Press, Oxford, 1995).

Cairns, R. "Outgrower Timber Schemes in Kwazulu-Natal: Do They Build Sustainable Rural Livelihoods and What Interventions Should be Made?" (Report prepared as part of the South Africa Country Study for the international collaborative research project steered by IIED: Instruments for sustainable private sector forestry, 2000).

Church, A., G. Groom, D. Thomson \& V. Dlamini "Small-scale Cane Grower Development Models: Some Lessons from Sub-Saharan Africa" Proceedings of the South African Sugar Technology Association 81 (2008) 116.

De Villiers, B. \& M. van den Berg, Land reform: Trailblazers; Seven Successful Case Studies (Konrad Adenauer-Stiftung, Johannesburg, 2006). 
Derman, B., E. Lahiff \& E. Sjaastad "Strategic Questions about Strategic Partners: Challenges and Pitfalls in South Africa's New Model of Land Restitution" in C. Walker, A. Bohlin, R. Hall \& T. Kepe (eds) Land, Memory, Reconstruction, and Justice: Perspectives on Land Claims in South Africa (Ohio University Press, 2010).

Hall, R. "A Political Economy of Land Reform in South Africa" (2004) 31 Review of African Political Economy 213.

Knight, S. \& M. Lyne "Perceptions of Farmworker Equity-share Schemes in South Africa" (2002) 41(4) Agrekon 356-374.

Lahiff, E. "Redistributive Land Reform and Poverty Reduction in South Africa" LaLR working paper (2007).

Lahiff, E. "Food Crisis Makes Effective Land Reform an Urgent Priority" (Mail \& Guardian 29 August 2008).

Lyne, M. \& M. Roth "Innovating Institutions to Help Land Reform Beneficiaries" (BASIS Brief Number 8, 2002).

Mini, S., R. Randela \& D. Mayson “Joint Venture Schemes: KZN, Western Cape, Mpumalanga, Eastern Cape" (research report, 2004) available at www.spp.org.za (accessed 25 October 2009).

Moyo, S. \& P. Yeros "Land Occupations and Land Reform in Zimbabwe: Towards the National Democratic Revolution" in S. Moyo \& P. Yeros (eds) Reclaiming the Land: The Resurgence of Rural Movements in Africa, Asia and Latin America (Zed Books, London and David Philip, Cape Town, 2005).

Porter, G. \& K. Phillips-Howard "Comparing Contracts: An Evaluation of Contract Farming Schemes in Africa" (1997) 25(2) World Development 227.

Rottger, A., A. Dannson, C. Ezedinma, T. Wambua, B. Bashasha, J. Kirsten \& K. Satorius "Strengthening farm-agribusiness linkages in Africa: Summary results of five country studies in Ghana, Nigeria, Kenya, Uganda and South Africa" (AGSF Occasional Paper 6, 2004).

Umhlaba Rural Services “A Review of LRAD Project Performance (2001-2006)" Report commissioned by the Department of Land Affairs (2008). 